\title{
Analysis on the Model of Cultivating Artisan Spirit from University Library
}

\author{
An-Ding LIU ${ }^{1, a}$ \\ ${ }^{1}$ Library, Wuhan Textile University, Wuhan, 430073, China \\ aada20040705@126.com
}

Keywords: Artisan spirit, University library, Inheritance, Innovation, Occupation.

\begin{abstract}
It is the core of artisan spirit that rigorous focus, attention to detail, excellence and dedication. The university library is an important place to cultivate the spirit of artisans. Therefore, the cultivation of the artisan spirit has come to a very important place. The article holds that the government needs to create a good social atmosphere for the cultivation of artisan spirit. The university library needs to formulate practical and concrete measures to cultivate craftsmanship. At the librarian level, it is necessary to exert its subjective initiative and work together to foster the craftsmanship.
\end{abstract}

\section{Introduction}

The mode of cultivation of craftsmen in university library should be "top-down" implementation process, the upper is the government level, the middle level is the university library level, the lower level is the university library librarian level. At the government level, there is an atmosphere in which artisans can cultivate their spirit. College library layers provide specific objective conditions for cultivating the spirit of artisans. Librarians also need to provide the internal drive to cultivate the spirit of artisans.

\section{Discussions and Analyses}

\section{University Library Calls for Craftsmanship}

\section{The Construction of an Innovative University Library Needs Strong Support from the Craftsman Spirit}

The craftsman's spirit is named after the "artisan" and can be concentrated in the artisanal community. But it is not unique to artisans, but for all walks of life with "rigorous focus, attention to detail, excellence, dedication," the quality of such people have the excellent spirit. Innovative Library refers to a library development model driven by innovation under the condition of knowledge economy. It evolves from the development and evolution of traditional library and digital library. It is the interaction between knowledge economy and information technology, a fusion of library evolution. [1]

As an important place for senior personnel training and scientific research, colleges and universities need the development of innovative businesses to meet the needs of teachers and students in teaching and research. Therefore, it is only the university librarians have the spirit of artisans can them to build innovative university library. First of all, the spiritual quality of librarians in colleges and universities determines the quality and level of their librarianship. To achieve the purpose of an innovative library, we must constantly revolve around the spirit of craftsmen, training librarians on the relevant knowledge (including library expertise and background information object) continuous learning and promotion, to achieve the point of excellence, love on the post Dedicated to the job, rigorous focus on the work, attention to detail, dare to upgrade the level of innovation and service to colleges and universities and even communities. Therefore, the training of university library librarian craftsmanship is conducive to promoting the construction of innovative university library. Second, the innovative library must be a research-based library. The main body of the library should also be a librarian who has research ability in a certain field and has the ability to create research-grade 
literature information. Only library personnel with research- Not rigidly adhere to the traditional services, to research-grade readers to play the role of information navigation, in order to be able to library and literature information in the forefront of a large area. As we all know, colleges and universities are the places where research-level talents (college teachers) gather, and transforming themselves into research-based innovative libraries is a necessary requirement for their own internal development. Therefore, the times call for colleges and universities to have research-based innovative university libraries, which in turn require their librarians to possess the spirit of craftsmanship.

\section{Cultivating the Spirit of Artisans in Colleges and Universities Needs the Vigorous Participation of University Libraries}

The main service targets of university library are undergraduates, teachers and administrators in the school. The main service of the university library is borrowing books, retrieving and checking information, and so on. The university library can play an extremely important role in nurturing the spirit of university craftsman.

First of all, the university library can provide abundant teaching and learning resources for the cultivation of artisan spirit in the process of "teaching" and "learning". On the one hand, university libraries can ensure that teachers are provided with the teaching resources needed by craftsmen to nurture them. As re-processors of knowledge, administrators, communicators and college librarians are fully capable of providing teachers with a large amount of professionally arranged spiritual resources of craftsmen and saving a large amount of time for document retrieval for teacher preparation. On the other hand, colleges and universities The library also provides university students with reading resources cultivated by "craftsmanship." Book reading is an important way to cultivate the spirit of artisans in college and the way of self-improvement by cultivating the spirit of artisans. Therefore, as long as the reasonable planning of the university library, it is entirely capable of establishing a database of book counters, electronic videos and audio materials cultivated by artisans. Give full play to the professional advantages of university libraries and make an important contribution to the cultivation of college students' craftsmanship.

Second, the university library can create a good internal and external environment for the cultivation of the spirit of student artisans. On the one hand, university library is the cultural center of colleges and universities, is a landmark building of colleges and universities. In the information age, it carries not only the long history of a university, but also the humanistic spirit imbued with this building, making it a collection of natural aesthetic and cultural aesthetics. [3] The author believes that the university library building also emits the spirit of artisan cohesion of its designers, builders. In the process of design, construction and management, university libraries emphasize how to effectively attract college students and create a good hardware environment for learning. Therefore, emphasizing innovation in the design process, attention to detail in the construction process. Eventually, having students see the library building immediately produces a shock to the craftsman's spirit. On the other hand, the library is not only the core of campus culture construction, but also the center of cultural education, which plays an important role in the cultivation of students' humanistic qualities. It is an important force for cultivating the spirit of student artisans. [4] The rich library and electronic resources owned by university libraries, especially high-quality librarians, can also demonstrate the rigorous, attention-to-detail, and improving craftsmanship of their ability to handle all kinds of resources.

\section{The Model of Cultivating Craftsman Spirit in University Library}

\section{The Government Needs to Create a Good Atmosphere for Cultivating Craftsmanship}

The spirit of university library artisans is not only a dedication, but also a service-oriented innovation. The development of the library artisan spirit needs the staff to establish a correct outlook on life, values, beliefs, good ideological and moral quality and a sound personality. A good social and cultural environment is a silent appeal to people's thoughts and behaviors. It can infiltrate the scientific theories, ideas and perspectives into people's ideology and help them to form noble 
ideological and moral qualities that meet the requirements of social development. Adhere to the correct direction of development. [5] Under the influence of extreme individualism, money worship and hedonism, people's outlook on life and values are more or less distorted, how to create a good social atmosphere to cultivate the spirit of craftsmen, it is particularly important.

The author believes that, first of all, the central and local governments at all levels should purify the media environment. On the one hand, they report more about the characters or deeds that reflect the craftsmanship from the perspective of propaganda. On the other hand, radio, television and media organizations at all levels should reduce, restrict and even prohibit the broadcasting of vulgar variety programs. Only in this trend of increasing, decreasing, the positive energy of society can be promoted, and the cultivation of artisan spirit can form a good social atmosphere. Second, governments at all levels should also guide and encourage the development of craftsmen's spirits in all trades and professions and even establish institutions for cultivating craftsmanship. They should encourage enterprises, agencies or individuals with craftsmanship in terms of policies, finance and taxation. In short, only at the government level to create a good atmosphere to cultivate the spirit of artisans, the cultivation of the spirit of university library artisans will have a good soil and climate, have the fruit of fruitful.

\section{The University Library Needs Concrete Measures To Cultivate the Spirit of Craftsmen}

In addition to the government needs to create a good social atmosphere to cultivate the spirit of craftsmen, university libraries also need to carry out specific planning in terms of rules and regulations, personnel training, the only way to provide practical support for the cultivation of the spirit of university library artisans.

First, university librarians are encouraged to work intensively and concentrate on the management and research of resources in a particular field of research. The main target of university library service is college teachers and students, they are very demanding on the information of the research field. According to the service function of the library, the library can be divided into a mass library and a research library, while most of the university library should belong to the research library. Therefore, I believe colleges and universities need to appropriately introduce some talents who possess the discipline background of colleges and universities when hiring librarians, and only in this way can they do new work or participate in relevant research projects of teachers so as to truly reflect the craftsmanship.

Second, to standardize the management of university libraries and to find certainty among the factors of uncertainty, is the key to the law-based and rules-based management of university libraries.

Thirdly, to establish a flexible and diversified system of personnel training and to some extent learn from the mentoring system of personnel training. Apprenticeship is an effective mechanism for cultivating talents in traditional industries in our country and is also suitable for library work. Through this mentoring-style training mode, the spirit of artisans embodied in the old librarian is passed on to the new recruits. In addition, they often organize old librarians to tell new librarians some of their experiences and experiences in their work.

\section{Librarians Need to Take the Initiative to Cultivate Their Own Artisan Spirit}

Librarians are the concrete implementers of the work of university libraries. To realize the craftsmanship in university libraries, the librarians must be transformed into artisans. The author believes that university library librarians take the initiative to cultivate their own artisan spirit can start from the following two aspects. First of all, librarians in a university library must make scientific and reasonable career plans for themselves. The so-called scientific and rational career planning refers to the librarians of colleges and universities combined with personal interests, professional expertise and requirements of the library digitization era, design their own development goals at all stages, and to achieve the set goals and the formation of new goals and requirements. [6] Obviously, the scientific and reasonable career planning of librarians in colleges and universities is to gradually form the quality of "rigorous focus, attention to detail and excellence".

Second, university librarians also need to enhance their professional ethics. The dedication and dedication demanded by artisans in college libraries carry strong subjective needs and correct value 
orientation. Such subjective demands and values constitute the intrinsic norms of librarians' practical activities and correct the problems in library professional practice Value goal of activity. [7] It is well known that the concept of "customer first, service first" is the professional credo of librarians. Therefore, every librarian in a university library should put the "reader first, service first" in the core creed of the work, actively communicate with teachers and students in colleges and universities around the needs of teachers and students in colleges and universities, The idea of teachers and students, and actively answer questions of teachers and students in the process of access to information in the process, so as to build a benign interaction between teachers and students.

\section{Conclusions}

The relationship between university library and artisan spirit is a mutual promotion and common development. First of all, the construction of an innovative university library needs artisan spirit, which is the requirements of the development of the university library itself. Secondly, the cultivation of students in colleges and universities need the university library as an important base, The new responsibility. The cultivation of craftsmen in university library should be carried out from top to bottom and need to be coordinated in three aspects: government, university library and its librarian. First of all, the government needs to create a good atmosphere for cultivating the spirit of artisans and provide great environmental protection for the cultivation of the artisans spirit in the university library. Secondly, the university library needs to formulate specific measures to cultivate the spirit of artisans, put into place, Nurture to provide the necessary objective conditions; Finally, the Librarians also need to play a subjective initiative, from the professional skills, professional ethics initiative to cultivate their own craftsman spirit.

\section{References}

[1] Qing-Li Bai. Concept model and development model of innovative library. Journal of Sichuan Library Science, 1(2011)6-9.

[2] Wei-Dong Zhu. Service-oriented, research-based library comparison. Library Science Research, 11(2004) 6-9, 13.

[3] Jin-Na Wang. Humanistic spirit of university library building. Journal of Library Science, 3 (2006)139-141.

[4] Bi-Lan Dai. Libraries in higher vocational students in the cultivation of the spirit and responsibility of artisans. Qingyuan Vocational and Technical College, 2(2017)71-75.

[5] Bao-Zhen Fu. Rational thinking of fostering library craftsmanship. Library Research, 1 (2017)45-52.

[6] Xiao-Ming Xu. Vocational college librarian career planning and management. Journal of Hebei University of Engineering (Social Science Edition), 2 (2012)119-121.

[7] Shen Ju. On the "craftsmanship" in the library work. Guotu Academy, 3 (2016)70-71. 